\title{
KAJIAN HUKUM TENTANG PENGUKURAN DAN PEMETAAN UNTUK PENDAFTARAN TANAH DITINJAU DARI PERATURAN MENTERI AGRARIA DAN TATA RUANG/KEPALA BADAN PERTANAHAN NASIONAL REPUBLIK INDONESIA NOMOR 1 TAHUN 2017 TENTANG PERUBAHAN ATAS PERATURAN MENTERI AGRARIA DAN TATA RUANG/KEPALA BADAN PERTANAHAN NASIONAL NOMOR 35 TAHUN 2016 TENTANG PERCEPATAN PELAKSANAAN PENDAFTARAN TANAH SISTEMATIS LENGKAP
}

\author{
Garda Viska Putra dan Hudali Mukti \\ Garda.bin.widodo@gmail.com, hudalimukti@ymail.com \\ Fakultas Hukum Universitas Widya Gama Mahakam Samarinda
}

\begin{abstract}
ABSTRAK
Pengukuran dan pemetaan bidang tanah untuk pendaftaran tanah merupakan perihal awal dalam rangka sertipikasi bidang tanah untuk memperoleh sertipikat hak atas tanah. Permasalahan dan kendala yang terjadi pada pengukuran dan pemetaan bidang tanah apabila tidak diberikan solusi yang pasti dapat menyebabkan sengketa bidang tanah semakin banyak. Pendaftaran Tanah Sistematis Lengkap merupakan salah satu upaya dari Kementerian Agraria dan Tata Ruang/Badan Pertanahan Nasional Republik Indonesia dalam rangka menyelesaikan permasalahan yang terjadi, antara lain belum terpetakannya bidang tanah yang bersertipikat hak atas tanah lama dan bidang lain yang belum bersertipikat hak atas tanah, memperbaiki metode pengukuran bidang tanah lama yang belum sesuai dengan kondisi saat ini, mengurai bidangbidang tanah yang mengalami sengketa bidang tanah.
\end{abstract}

Kata Kunci: Pengukuran, Pemetaan, Pendaftaran Tanah.

\begin{abstract}
The measurement and mapping of land parcels for land registration is the initial subject in the framework of land certification to obtain a land title certificate. Problems and constraints that occur in the measurement and mapping of land parcels if not given a solution that can certainly cause more land disputes. Complete Systematic Land Registration is one of the efforts of the Ministry of Agrarian Affairs and Spatial Planning or the National Land Agency of the Republic of Indonesia in order to resolve the problems that occur, including the uncharted land parcels with old land titles and other fields that have not been granted land titles. a method of measuring the old parcels of land that are not in accordance with the current conditions, parsing land parcels that have experienced land disputes.
\end{abstract}

Keywords: Measurement, Mapping, Land Registration. 


\section{PENDAHULUAN}

\section{A. Latar Belakang}

Program Presiden Republik Indonesia Bapak Joko Widodo dalam rangka mendukung tujuan Strategi Nasional Keuangan Inklusif (SNKI) dimana pada tahun 2019 sebanyak tujuh puluh lima persen penduduk Indonesia memiliki akses ke layanan keuangan dengan melakukan percepatan penerbitan sertipikat tanah. Target tersebut meliputi sertipikasi lima juta bidang tanah pada tahun 2017, pada tahun 2018 ditargetkan tujuh juta bidang tanah, dan pada tahun 2019 ada sembilan juta bidang tanah.

Menteri Agraria dan Tata Ruang/Kepala Badan Pertanahan Nasional (Menteri ATR/BPN) yang saat ini dijabat oleh Bapak Dr. Sofyan A. Djalil, S.H., M.A., M.ALD. berusaha mengupayakan program pemerintah untuk menyelesaikan sertipikasi lima juta bidang tanah milik masyarakat pada tahun ini. Kendala yang dihadapi yaitu masalah anggaran pemerintah yang terbatas ditambah minimnya tenaga petugas ukur yang merupakan tombak berjalannya program tersebut.

Peraturan Menteri Agraria dan Tata Ruang/Kepala Badan Pertanahan Nasional Republik Indonesia Nomor 1 Tahun 2017 tentang Perubahan atas Peraturan Menteri Agraria dan Tata Ruang/Kepala Badan Pertanahan Nasional Nomor 35 Tahun 2016 tentang Percepatan Pelaksanaan Pendaftaran Tanah Sistematis Lengkap merupakan salah satu upaya dalam melaksanakan program presiden tersebut. Diharapkan dengan adanya payung hukum tersebut proses sertipikasi bidang tanah melalui percepatan Pendaftaran Tanah Sistematis Lengkap (PTSL) dapat terlaksana dengan maksimal, khususnya dalam pelaksanaan pengukuran dan pemetaan bidang tanah yang merupakan dasar dari penerbitan sertipikat selain dari data yuridis pemilik bidang tanah.

Jumlah petugas pengukuran yang dimiliki Kementerian ATR/BPN saat ini sekitar 2.500 petugas ukur di seluruh Indonesia dirasa masih kurang dalam menghadapi beban kerja lima juta bidang tanah dalam satu tahun. Petugas pemetaan yang seharusnya berbeda dengan petugas pengukuran sebagai koreksi terhadap pekerjaan pengukuran bidang tanah juga merangkap menjadi petugas ukur. Ditambah penyebaran jumlah petugas ukur yang tidak seimbang antara di Pulau JawaBali dengan di luar Pulau Jawa-Bali, menjadikan beban tambahan bagi petugas ukur.

\section{B. Permasalahan}

Adapun permasalahan dari latar belakang tersebut diatas adalah :

1. Bagaimana permasalahan pengukuran dan pemetaan bidang tanah untuk pendaftaran tanah ditinjau dari Peraturan Menteri Agraria Dan Tata Ruang/Kepala Badan Pertanahan Nasional Republik Indonesia Nomor 1 Tahun 2017 Tentang Perubahan Atas Peraturan Menteri Agraria Dan Tata Ruang/Kepala Badan Pertanahan Nasional Nomor 35 Tahun 2016 Tentang Percepatan Pelaksanaan Pendaftaran Tanah Sistematis Lengkap ?

2. Bagaimana mengatasi permasalahan pengukuran dan pemetaan bidang tanah untuk pendaftaran tanah ditinjau dari Peraturan Menteri Agraria Dan Tata Ruang/Kepala Badan Pertanahan Nasional Republik Indonesia Nomor 1 Tahun 2017 Tentang Perubahan Atas Peraturan Menteri Agraria Dan Tata Ruang/Kepala Badan Pertanahan Nasional Nomor 35 Tahun 2016 
Tentang Percepatan Pelaksanaan Pendaftaran Tanah Sistematis Lengkap ?

\section{Tujuan dan Manfaat Penelitian}

Adapun Penelitian ini bertujuan untuk Untuk mengetahui permasalahan pengukuran dan pemetaan bidang tanah untuk pendaftaran tanah dan untuk menemukan cara mengatasi permasalahan pengukuran dan pemetaan bidang tanah untuk pendaftaran tanah.

Penelitian ini diharapkan tidak hanya memberikan manfaat baik secara teoritis maupun praktisi yaitu dengan menambah wawasan agar lebih mengerti dan memahami teori - teori yang didapat selama perkuliahan dimana berhubungan dengan ilmu hukum pertanahan dan dapat menemukan solusi praktis terhadap masalah pertanahan yang terjadi terutama pada sektor pengukuran dan pemetaan bidang tanah, dan penelitian ini diharapkan memberikan sumbangan kepustakaan sebagai informasi tambahan yang berguna bagi pembaca dan dapat memberikan sumbangan pemikiran bagi pihak-pihak yang mempunyai permasalahan yang sama atau ingin mengadakan penelitian lebih lanjut.

\section{METODE PENELITIAN}

\section{A. Jenis Penelitian dan Sumber Data}

Jenis penelitian yang digunakan dalam penelitian adalah pendekatan yuridis normative. Pendekatan Yuridis Normatif adalah pendekatan yang dilakukan berdasarkan bahan hukum utama dengan cara menelaah teori-teori, konsep-konsep, asas-asas hukum serta peraturan perundangundangan yang berhubungan dengan penelitian ini. Metode ini menyangkut ketentuan hukum normatif peraturan maupun undang-undang yang sudah ada, dalam penerapannya terjadi pada lingkungan masyarakat yang ikut andil dalam kesesuaian peraturan tersebut dengan kondisi masyarakat pada saat sekarang. Hukum Normatif atau penelitian perpustakaan ini merupakan penelitian yang mengkaji studi dokumen, yakni menggunakan berbagai data sekunder seperti peraturan perundang-undangan, keputusan pengadilan, teori hukum, dan dapat berupa pendapat para sarjana.

Sumber data yang digunakan dalam penelitian ini terdiri dari 3 (tiga) bahan hukum yaitu sumber hukum primer yaitu berupa Undang-Undang Republik Indonesia Nomor 5 Tahun 1960 Tentang Peraturan Dasar Pokok-Pokok Agraria, Peraturan Pemerintah Republik Indonesia Nomor 24 Tahun 1997 Tentang Pendafratan Tanah, Peraturan Menteri Negara Agraria/Kepala Badan Pertanahan Nasional Nomor 3 Tahun 1997 Tentang Ketentuan Pelaksanaan Peraturan Pemerintah Nomor 24 Tahun 1997 Tentang Pendaftaran Tanah, Peraturan Menteri Agraria Dan Tata Ruang/Kepala Badan Pertanahan Nasional Republik Indonesia Nomor 35 Tahun 2016 Tentang Percepatan Pelaksanaan Pendaftaran Tanah Sistematis Lengkap, Peraturan Menteri Agraria Dan Tata Ruang/Kepala Badan Pertanahan Nasional Republik Indonesia Nomor 1 Tahun 2017 Tentang Perubahan Atas Peraturan Menteri Agraria Dan Tata Ruang/Kepala Badan Pertanahan Nasional Nomor 35 Tahun 2016 Tentang Percepatan Pelaksanaan Pendaftaran Tanah Sistematis Lengkap, Peraturan Menteri Agraria dan Tata Ruang/Kepala Badan Pertanahan Nasional Republik Indonesia Nomor 33 Tahun 2016 Tentang Surveyor Kadaster Berlisensi, Peraturan Menteri Agraria dan Tata Ruang/Kepala Badan Pertanahan Nasional Republik Indonesia Nomor 28 Tahun 2016 Tentang Percepatan Program Nasional Agraria Melalui Pendaftaran Tanah Sistematis, Peraturan Kepala Badan Informasi Geospasial Nomor 15 Tahun 
2014 tentang Pedoman Teknis Ketelitian Peta Dasar.

Bahan hukum sekunder yang memberikan penjelasan mengenai bahan hukum primer, seperti rancangan UndangUndang, hasil-hasil penelitian, hasil karya dari kalangan hukum dan seterusnya. Dan bahan Hukum Tertier, yakni bahan yang memberikan petunjuk maupun penjelasan terhadap bahan hukum primer dan sekunder, contohnya adalah kamus, ensiklopedia, indeks kumulatif dan sebagainya.

\section{B. Teknik Pengumpulan Data}

Pengumpulan data dalam berupa studi dokumen atau kepustakaan yaitu dengan cara untuk memperoleh data dengan mempelajari dan menganalisa bahan pustaka yang berkaitan dengan permasalahan penelitian, dan melakukan wawancara dengan narasumber untuk memperoleh data dengan mengajukan pertanyaan secara lisan yang jawabannya diserahkan kepada responden. Wawancara tak berstruktur sering juga disebut teknik wawancara mendalam, karena peneliti merasa tidak tahu apa yang belum diketahuinya.

wawancara dilakukan dengan pertanyaan yang bersifat open-ended, dan mengarah pada kedalaman informasi, serta dilakukan dengan cara yang tidak secara formal berstruktur guna menggali pandangan subyek yang diteliti tentang banyak hal yang sangat bermanfaat untuk menjadi dasar bagi penggalian informasinya secara lebih jauh dan mendalam. Oleh karena itu dalam hal ini subyek yang diteliti posisinya lebih berperan sebagai informan daripada sebagai responden.

\section{Analisis Data}

Analisis yang digunakan dalam penelitian ini adalah metode kualitatif, adapun yang dimaksud dengan analisa kualitatif adalah suatu tata cara penelitian yang menghasilkan data deskriptif analisa, yaitu apa yang dinyatakan responden secara tertulis atau lisan dan juga perilaku nyata, yang diteliti dan dipelajari sebagai suatu yang utuh. Sedangkan analisis kualitatif yang digunakan medel interaktif, yaitu komponen reduksi data, sajian data dilakukan bersama dengan pengumpulan data, dan setelah data terkumpul, maka tiga komponen tersebut berinteraksi, apabila kesimpulan dilaksanakan kurang kuat, maka perlu ada verifikasi dan peneliti kembali mengumpulkan data di lapangan.

\section{PEMBAHASAN}

\section{A. Pengukuran dan Pemetaan Untuk} Pendaftaran Tanah ditinjau dari Peraturan Menteri Agraria Dan Tata Ruang/Kepala Badan Pertanahan Nasional Republik Indonesia Nomor 1 Tahun 2017 Tentang Perubahan Atas Peraturan Menteri Agraria Dan Tata Ruang/Kepala Badan Pertanahan Nasional Nomor 35 Tahun 2016 Tentang Percepatan Pelaksanaan Pendaftaran Tanah Sistematis Lengkap

Dalam rangka memperjelas dan memperkuat serta mendukung uraian dari permasalahan yang telah diuraikan diawal, maka penulis menyajikan data hasil penelitian yang selanjutnya dianalisis untuk memperoleh kesimpulan. Dalam hal ini penulis melakukan analisis terhadap hasil wawancara yang diperoleh penulis serta studi kepustakaan peraturan perundangan yang terkait dengan permasalahan tersebut.

Berdasarkan hasil wawancara yang dilakukan di Kantor Pertanahan Kota Samarinda dan Kantor Wilayah Badan Pertanahan Nasional Provinsi Kalimantan Timur bahwa pelaksanaan kegiatan 
Pendaftaran Tanah Sistematik Lengkap dalam hal pengukuran dan pemetaan dapat dibagi menjadi 3 (tiga) bagian antara lain:

1. Kegiatan Sosialisasi dan/atau Penyuluhan.

Sosialisasi dan penyuluhan terhadap masyarakat sebagai pemilik bidang tanah belum sepenuhnya mengena dan dipahami oleh masyarakat tersebut. Dalam Kamus Besar Bahasa Indonesia "Sosialisasi adalah usaha untuk mengubah milik perseorangan menjadi milik umum (milik negara), Proses belajar seorang anggota masyarakat untuk mengenal dan menghayati kebudayaan masyarakat dalam lingkungannya, dan upaya memasyarakatkan sesuatu sehingga menjadikan dikenal, dipahami, dihayati oleh masyarakat, pemasyarakatan. ${ }^{1} \quad$ Sedangkan Penyuluhan dalam Kamus Besar Bahasa Indonesia "penyuluhan adalah proses, cara, perbuatan menyuluh, Penerangan, dan Pengintaian, penyelidikan. $^{2}$

2. Kegiatan Pengukuran

Permasalahan pengukuran dapat dibedakan menjadi beberapa kelompok antara lain:

a. Pemasangan Tanda Batas Bidang Tanah;

b. Penunjukan Batas Bidang Tanah dan Peran Aktif Masyarakat;

c. Alas Hak Atas Tanah;

d. Peralatan dan Tenaga Pengukuran.

3. Kegiatan Pemetaan

Permasalahan pemetaan dapat dibedakan menjadi beberapa kelompok antara lain:

a. Pembuatan Peta Bidang;

17 http://kbbi.web.id/sosialisasi, 8 September 2017, 20.00 WITA.

2 http://kbbi.web.id/penyuluhan, 8 September 2017, 20.20 WITA. b. Bidang Tanah tidak sesuai dengan Tata Ruang.

B. Mengatasi

Permasalahan

Pengukuran dan Pemetaan Bidang Tanah Untuk Pendaftaran Tanah ditinjau dari Peraturan Menteri Agraria Dan Tata Ruang/Kepala Badan Pertanahan Nasional Republik Indonesia Nomor 1 Tahun 2017 Tentang Perubahan Atas Peraturan Menteri Agraria Dan Tata Ruang/Kepala Badan Pertanahan Nasional Nomor 35 Tahun 2016 Tentang Percepatan Pelaksanaan Pendaftaran Tanah Sistematis Lengkap.

1. Kegiatan Sosialisasi dan/atau Penyuluhan

Kegiatan Sosialisasi sudah tercantum pada Pasal 3 ayat (3) Peraturan Menteri Agraria dan Tata Ruang/Kepala Badan Pertanahan Nasional Republik Indonesia Nomor 1 Tahun 2017 Tentang Perubahan Atas Peraturan Menteri Agraria Dan Tata Ruang/Kepala Badan Pertanahan Nasional Nomor 35 Tahun 2016 Tentang Percepatan Pelaksanaan Pendaftaran Tanah Sistematis Lengkap membahas tahapan Pendaftaran Tanah Sistematis Lengkap antara lain:

a. Penetapan lokasi kegiatan percepatan Pendaftaran Tanah Sistematis Lengkap;

b. Pembentukan dan penetapan Panitia Ajudikasi Pendaftaran Tanah Sistematis Lengkap;

c. Penyuluhan;

d. Pengumpulan dan pengolahan Data Fisik dan Data Yuridis bidang tanah;

e. Pemeriksaan tanah;

f. Pengumuman Data Fisik dan Data Yuridis;

g. Penerbitan keputusan pemberian Hak atas Tanah;

h. Pembukuan Hak atas Tanah; 
i. Penerbitan Sertipikat Ha katas Tanah dan/atau

j. Penyerahan Sertipikat Hak atas Tanah.

Hal tersebut diperjelas kembali melalui Petunjuk Teknis Nomor: 01/JUKNIS-400/XII/2016 Tentang Percepatan Pelaksanaan Pendafataran Tanah Sistematis Lengkap Bidang Yuridis yang menyebutkan:

a. Persiapan (Sosialisasi, Penetapan Lokasi, Perencanaan Tenaga Dan Pembentukan Panitia Ajudikasi Percepatan, Pelatihan).

Persiapan dilakukan pada Bulan Kesatu (B.1);

Kegiatan persiapan meliputi:

1.) Sosialisasi;

2.) Penetapan Lokasi dan Jumlah Bidang;

3.) Perencanaan tenaga panitia dan Satgas Yuridis;

4.) Pembentukan Panitia Ajudikasi Percepatan;

5.) Pelatihan.

b. Penyuluhan

Penyuluhan dilakukan selambatlambatnya pada Bulan Kedua (B.2);

1.) Penyuluhan dilakukan oleh Kantor Pertanahan beserta Panitia Ajudikasi Percepatan dan Satgas Yuridis bersama Satgas Fisik;

2.) Dalam penyuluhan disampaikan tahapan kegiatan Pendaftaran tanah Sistematis Lengkap, dokumen yuridis yang perlu disiapkan, jadwal pengumpulan data yuridis, kluster hasil akhir kegiatan ajudikasi percepatan;

3.) Mengajak partisipasi masyarakat dalam pelaksanaan Pendaftaran Tanah Sistematis Lengkap dengan memperhatikan hak dan kewajibannya;

4.) Penjelasan tentang pembiayaan yang disediakan oleh Pemerintah melalui kegiatan Pendaftaran Tanah Sistematis Lengkap dan kemungkinan biaya/bea/pajak yang akan ditanggung oleh peserta.

c. Pengumpulan Data Yuridis

Pengumpulan data yuridis dilakukan selambat-lambatnya pada Bulan Ketiga (B.3);

d. Pengolahan Data Yuridis dan Pembuktian Hak

Data yuridis yang diinventarisasi/terkumpul dilakukan analisis oleh Panitia Ajudikasi Percepatan, menyangkutdata kepemilikan yang menunjukkan hubungan hukum antara peserta Pendaftaran Tanah Sistematis Lengkap dengan tanah obyek Pendaftaran Tanah Sistematis Lengkap;

e. Pemeriksaan Tanah

Pemeriksaan tanah dilakukan untuk memastikan keterangan yang tertuang di dalam data yuridis sesuai dengan keadaan dilapangan. Dilakukan dengan cara menggali informasi yang meliputi kesesuaian nama dan profesi peserta Pendaftaran Tanah Sistematis Lengkap. Membandingkan keterangan yang tertera di dalam formulir isian inventarisasi dan dokumen/data yuridis dengan kesesuaian dengan kondisi penguasaan, penggunaan tanah tersebut di lapangan, serta keseuaian letak, batas dan luas yang tertuang dalam data fisik (Peta Bidang Tanah) dengan kenyataan di lapangan. Hasil pemeriksaan tanah mendukung analisis terhadap data yuridis yang menghasilkan K1, K2, K3, dan K4. Hasil pemeriksaan tanah dimuat dalam Daftar Isian sesuai dengan Lampiran 8b: Risalah Penelitian Data Yuridis dan Penetapan Batas;

f. Pengumuman

Hasil pemeriksaan tanah yang menyimpulkan dapat dibukukan dan atau diterbitkannya Sertipikat hak atas tanah atas satu bidang tanah diumumkan dalam papan pengumuman di Kantor Pertanahan 
dan/atau Kantor Kelurahan/Desa dan/atau Sekretariat RT/RW lokasi bidang tanah tersebut selama 14 hari kerja, dengan tujuan untuk diketahui khalayak masyarakat dan memberi kesempatan kepada pihka-pihak yang berkepentingan untuk menyampaikan keberatan jika ada keberatan;

g. Pengesahan

Hasil dari pengumuman disahkan dalam Berita Acara Hasil Pengumuman oleh Panitia Ajudikasi Percepatan;

h. Penerbitan Surat Keputusan Penetapan Hak dan Keputusan Penegasan/Pengakuan Hak

i. Pembukuan Hak

j. Penerbitan dan penyerahan Sertipikat

k. Pengelolaan Warkah/Dokumen

1. Pelaporan

Untuk menghindari sengketa bidang tanah yang akan terjadi dikemudian hari maka dalam memeriksa berkas permohonan yang diajukan oleh pemilik tanah harus sesuai dengan peraturan yang berlaku seperti yang tersebut dalam tulisan supriadi berikut:

Dalam memeriksa kelayakan sebuah permohonan yang diajukan oleh pemohon, maka lahan tersebut akan diuji dan berkesimpulan:

a. Bahwa lahan yang dimohon didaftarkan tersebut baik dan jelas;

b. Bahwa atas permohonan tidak ada sengketa dalam pemilikan tersebut;

c. Bahwa atas permohonannya secara meyakinkan dapat diberikan;

d. Bahwa atas bukti dari alas hak tidak ada orang yang berprasangka dan berkeberatan terhadap kemilikan pemohon. ${ }^{3}$

Pentingnya memberitahu tentang pelaksanaan kegiatan ini tidak bisa

3 Supriadi, 2016, Hukum Agraria, Sinar Grafika, Jakarta, hlm. 167. dianggap remeh sehingga harus tepat sasaran dalam melaksanakan penyuluhan.

Penyuluhan

bertujuan

memberitahukan kepada pemegang hak atau kuasanya atau pihak lain yang berkepentingan bahwa di desa/kelurahan tersebut akan diselenggarakan pendaftaran tanah secara sistematik ddan tujuan serta manfaat yang akan diperoleh dari hasil pendaftaran tanah tersebut. ${ }^{4}$

\section{Kegiatan Pengukuran}

Sebelum melaksanakan kegiatan pengukuran diharapkan petugas pengukuran melaksanakan persiapan sesuai dengan Pasal 8 Peraturan Menteri Agraria dan Tata Ruang/Kepala Badan Pertanahan Nasional Republik Indonesia Nomor 1 Tahun 2017 Tentang Perubahan Atas Peraturan Menteri Agraria Dan Tata Ruang/Kepala Badan Pertanahan Nasional Nomor 35 Tahun 2016 Tentang Percepatan Pelaksanaan Pendaftaran Tanah Sistematis Lengkap menyebutkan tahapan pengumpulan data fisik.

Selain itu diharapkan petugas pengukuran melaksanakan kegiatannya sesuai dengan Petunjuk Teknis Pengukuran Dan Pemetaan Bidang Tanah Sistematik Lengkap Nomor: 01/JUKNIS-300/2016, Tanggal : 30 Desember 2016, menyebutkan pengukuran dan pemetaan bidang tanah sistematis lengkap dilaksanakan setelah desa/kelurahan atau nama lain yang setingkat tersebut menjadi lokasi Pendaftaran Tanah Sistematis Lengkap. Dalam menetapkan lokasi sebaiknya mempertimbangkan ketersediaan Peta Dasar untuk menunjang kelancaran pelaksanaan pekerjaan. Selain itu, agar dapat dicapai pemetaan lengkap desa demi desa, maka dalam penetapan lokasi wajib

\footnotetext{
${ }^{4}$ Umar Said Sugiharto, (et.al.), 2015, Hukum Pengadaan Tanah Pengadaan Hak Atas Tanah untuk Kepentingan Umum Pra dan Pasca Reformasi, Setara Press, Malang, Jatim, hlm. 260.
} 
memperhatikan seluruh bidang tanah dalam satuan wilayah desa/kelurahan atau sebutan lain yang setingkat tersebut dapat diukur dan dipetakan secara lengkap. Berikut tahap-tahap dalam pelaksanaan pengukuran dan pemetaan bidang tanah menurut Petunjuk Teknis Pengukuran Dan Pemetaan Bidang Tanah.

Ditambah beberapa hal yang tidak boleh terlupakan sebagai petugas pengukuran sesuai dengan Sebelum melaksanakan pengukuran bidang tanah ada hal-hal yang harus dipersiapkan yang berkaitan dengan kegiatan pengukuran tersebut, salah satunya seperti yang tercantum pada Buku Pegangan Juru Ukur.

Permasalahan pengukuran yang ditemukan beberapa diantaranya dapat diselesaikan dengan cara sebagai berikut:

a. Pemasangan Tanda Batas Bidang Pemasangan tanda batas bidang tanah adalah permasalahan yang paling sering ditemui oleh petugas pengukuran baik dalam pelaksanaan pendaftaran tanah sporadik apalagi dalam pendaftaran tanah sistematis.

Sebagaimana Noer Fauzi, bahwa James C. Riddel merumuskan tentang: Penguasaan dan pemilikan atas tanah adalah "abundle of right", dimana masingmasing hak dapat dilekatkan pada individu, atau entitas ekonomi politik bahkan agama. Setiap sistem penguasaan tanah (land tenurial system), pada prinsipnya memiliki tiga komponen utama:

1.) Adanya subyek hak;

2.) Obyek hak yang berupa persil tanah, yang diberi batas-batas dengan simbol tertentu;
3.) Jenis haknya, setiap hak selalu dapat dijelaskan batasannya, yang membedakannya dengan hak yang lain. $^{5}$

Tidak terpasangnya tanda batas bidang tanah atau yang lebih sering dikenal patok batas dapat mengakibatkan sengketa bidang tanah pada kemudian hari dan tidak dapat dilakukan pengukuran bidang tanah secara pasti karena tidak adanya obyek yang dijadikan patokan pengukuran.

Dalam hal terjadi sengketa mengenai batas bidang-bidang tanah yang berbatasan, Panitia Ajudikasi dalam pendaftaram tanah secara sistematik atau Kepala Kantor Pertanahan/petugas pengukuran yang ditunjuk dalam pendaftaran tanah secara sporadik berusaha menyelesaikannya secara damai melalui musyawarah antara pemegang hak dan pemegang ha katas tanah yang berbatasan, yang apabila berhasil penetapan batas yang dihasilkannya dituangkan dalam Risalah Penyelesaian Sengketa Batas (daftar isian 200). ${ }^{6}$

b. Penunjukan Batas Bidang Tanah dan Peran Aktif Masyarakat

Pelaksanaan program Pendaftaran Tanah Sistematis Lengkap tidak akan terlaksana dengan baik apabila tidak ada peran aktif dari masyarakat secara menyeluruh dalam mensukseskan program tersebut.

Penetapan batas bidang tanah diupayakan penataan batas berdasarkan kesepakatan para pihak yang berkepentingan. Penempatan tanda-tanda batas termasuk pemeliharaannya wajib

5 Farida Fitriyah, 2016, Hukum Pengadaan Tanah Transmigrasi, Setara Press, Malang, Jatim, hlm. 35 .

${ }^{6}$ Waskito \& Hadi Arnowo, 2015, Cara Praktis Memahami Bidang Agraria (Pertanahan), PT. Media Adji Internasional, Jakarta Timur, hlm. 32. 
dilakukan oleh pemegang hak atas tanah yang bersangkutan. ${ }^{7}$

Peran dari desa atau kelurahan juga merupakan hal penting untuk melaksanakan program tersebut. Program lain dari Badan Pertanahan Nasional juga dialihkan untuk masuk ke dalam program Pendaftaran Tanah Sistematis Lengkap contohnya Program Nasional Agraria yang biasa dikenal dengan PRONA. Dalam Peraturan Menteri Agraria dan Tata Ruang/Kepala Badan Pertanahan Nasional Republik Indonesia Nomor 28 Tahun 2016 Tentang Percepatan Program Nasional Agraria Melalui Pendaftaran Tanah Sistematis Bab VI Ketentuan Lain-lain Pasal 16 menyebutkan:

1.) Dalam hal pendanaan percepatan PRONA melalui Pendaftaran Tanah Sistematis sebagaimana dimaksud dalam Pasal 15 ayat (1) tidak mencukupi, maka pengumpulan Data Fisik dan Data Yuridis serta pembukuan tanah tetap terus dilaksanakan hingga lengkap satu desa/kelurahan, dengan jaminan bahwa sisa pendanaan yang belum terbayar dalam tahun anggaran berjalan merupakan pendanaan/anggaran terhutang yang akan dilunasi melalui pendanaan anggaran perubahan atau anggaran tahun berikutnya;

2.) Dalam hal pendanaan percepatan PRONA melalui Pendaftaran Tanah Sitematis sebagaimana dimaksud dalam Pasal 15 ayat (2) tidak mencukupi, maka pengumpulan Data Fisik dan Data Yuridis serta pembukuan tanah tetap terus dilaksanakan hingga lengkap satu desa/kelurahan, dengan jaminan bahwa sisa pendanaan yang belum terbayar dalam tahun anggaran berjalan, merupakan pendanaan yang terhutang dari perjanjian kerjasama dengan pihak lain atau dari keputusan swadaya masyarakat, yang akan dilunasi melalui addendum pendanaan perjanjian kerjasama atau keputusan swadaya masyarakat dimaksud.

c. Alas Hak Atas Tanah

Pendaftaran tanah tidak bisa lepas dari dasar penguasaan dan pemilikan lahan bidang tanah yang didaftarkan. Untuk memudahkan kelengkapan berkas yang dianggap terlalu rumit, Kementerian Agraria Dan Tata Ruang/Badan Pertanahan Nasional menerbitkan Petunjuk Pelaksanaan Pendaftaran Tanah Masyarakat Nomor: 1756/15.1/IV/2016, tanggal 14 April 2016 menyebutkan:

Dalam rangka untuk menjamin kepastian hukum hak atas tanah masyarakat dan untuk meningkatkan kesejahteraan masyarakat melelaui pendaftaran tanah, perlu dilakukan percepatan pendaftaran tanah dengan memberikan kemudahan bagi masyarakat yang akan mendaftarkan tanahnya, bahwa mengingat masih terdapat masyarakat yang menguasai tanah namun tidak mempunyai bukti-bukti kepemilikan tanah (alas hak) secara lengkap dan bahkan sama sekali tidak mempunyai bukti kepemilikan, sehingga terkendala dalam permohonan pendaftaran hak atas tanahnya.

Sehubungan hal tersebut di atas, dalam rangka memberikan kemudahan untuk percepatan pendaftaran tanah masyarakat dan untuk meringankan beban pembiayaan pendaftaran tanah bagi mesyarakat, maka dengan ini diinstruksikan hal sebagai berikut: 
1.) Melakukan percepatan kegiatan pendaftaran tanah di Seluruh Indonesia baik melalui dana Pemerintah maupun dana swadaya masyarakat;

2.) Dalam hal dasar penguasaan dan/atau bukti kepemilikan tanah masyarakat tidak lengkap atau sama sekali tidak mempunyai dasar penguasaan dan/atau bukti kepemilikan tanah agar dibuktikan dengan surat pernyataan tertulis tentang penguasaan fisik bidang tanah dengan itikad baik dari yang bersangkutan;

3.) Itikad baik sebagaimana tersebut di atas dibuktikan sebagai berikut:
a.) Tidak terdapat keberatan dari pihak lain atas tanah yang dikuasai/tidak dalam sengketa;
b.) Tidak termasuk sebagai aset Pemerintah atau Pemerintah Daerah;
c.) Tidak termasuk dalam kawasan hutan.

4.) Surat pernyataan sebagaimana dimaksud di atas dibuat dengan disaksikan paling sedikit 2 (dua) orang saksi dari lingkungan setempat yang tidak mempunyai hubungan keluarga dengan yang bersangkutan sampai derajat kedua, baik dalam kekerabatan vertikal maupun horizontal yang menyatakan bahwa yang bersangkutan adalah benar sebagai pemilik dan menguasai bidang tanah tersebut;

5.) Surat pernyataan tersebut dibuat berdasarkan keterangan yang sebenarbenarnya dan pihak yang membuat pernyataan bertanggung jawab baik secara perdata maupun pidana apabila di kemudian hari terdapat unsur-unsur ketidakbenaran dalam pernyataannya dan bersedia sertipikatnya dibatalkan dan diproses hukum sesuai peraturan yang berlaku serta tidak melibatkan pihak lain;

Kepemilikan bidang tanah tersebut kebanyakan berasal dari tanah Negara bebas yang secara turun temurun digarap dan dikuasai oleh masyarakat. Hak atas tanah bersumber dari hak menguasai negara atas tanah dapat diberikan kepada perseorangan baik Warga Negara Indonesia (WNI) maupun Warga Negara Asing (WNA), sekelompok orang secara bersamasama dan badan hukum baik badan hukum privat maupun badan hukum publik. ${ }^{8}$ Dari segi asal tanahnya, hak atas tanah dibedakan menjadi 2 (dua) kelompok, yaitu:

1.) Hak atas tanah yang bersifat primer, yaitu atas tanah yang berasal dari tanah Negara. Macam-macam ha katas tanah ini adalah hak milik, hak guna usaha, hak guna bangunan atas tanah negara, hak pakai atas tanah negara.

2.) Hak atas tanah yang bersifat sekunder, yaitu ha katas tanah yang berasal dari pihak lain. Macam-macam ha katas tanah ini adalah hak guna bangunan di tanah hak pengelolaan, hak guna bangunan atas tanah hak milik, hak pakai atas tanah hak sewa untuk bangunan, hak gadai (gadai tanah), hak usaha bagi hasil (perjanjian bagi hasil), hak menumpang dan hak sewa tanah pertanian. ${ }^{9}$

Permohonan pendaftaran tanah dapat juga berasal dari tanah konversi lama dan dibedakan menjadi beberapa kriteria sebagai berikut:

\footnotetext{
${ }^{8}$ Urip Santoso, 2005, Hukum Agraria dan Hakhak Atas Tanah, Kencana dan Prenada Media, Jakarta, hlm. 87.

9 Wira Franciska, 2016, Kepastian Hukum Pemegang HGB Di Atas HPL Dalam Perjanjian Penjaminan Kredit Perbankan, Alfabeta, CV, Bandung, hlm. 71.
} 
1.) Permohonan yang dapat di Konversi langsung apabila dapat alat bukti haknya dinyatakan lengkap. ${ }^{10}$

2.) Dalam hal tidak atau tidak lagi tersedia secara lengkap alat-alat pembuktian, maka penaskahan hak dapat dilakukan berdasarkan kenyataan penguasaan fisik bidang tanah yang bersangkutan selama 20 (dua puluh) tahun atau lebih secara berturut-turut oleh pemohon pendaftaran dan pendahulupendahulunya. ${ }^{11}$

3.) Dalam hal bukti-bukti mengenai kepemilikan tanah tidak ada, maka permohonan tersebut harus disertai dengan surat pernyataan dan keterangan dari Kepala Desa. ${ }^{12}$

\section{d. Peralatan dan Tenaga Pengukuran}

Peralatan pengukuran dapat dipakai dengan beberapa metode sesuai dengan ketersediaan alat yang dimiliki, jadi tidak harus menggunakan alat paling muthakir dalam pelaksanaan kegiatan pengukuran.

Penambahan tenaga petugas
pengukuran sudah dipikirkan oleh Kementerian Agraria Dan Tata Ruang/Badan Pertanahan Nasional dengan menerbitkan Peraturan Menteri Agraria dan Tata Ruang/Kepala Badan Pertanahan Nasional Republik Indonesia Nomor 33 Tahun 2016 Tentang Surveyor Kadaster Berlisensi yang menyebutkan pada Bagian Ketiga : Asal Pekerjaan, Ruang Lingkup dan Tanggung Jawab Pekerjaan, Pasal 10 sampai Pasal 13.

\section{Kegiatan Pemetaan}

Kegiatan Pemetaan merupakan tahap terusan setelah pengukuran bidang tanah. Karena pengukuran bidang tanah apabila tidak dituangkan dalam bentuk peta tidak akan bisa dipakai atau diberikan ha katas

\footnotetext{
${ }^{10}$ Waskito \& Hadi Arnowo, Op.cit., hlm. 27.

${ }^{11}$ Waskito \& Hadi Arnowo, Ibid., hlm. 29.

12 Waskito \& Hadi Arnowo, Ibid.
}

tanahnya tersebut. Oleh karena itu Pemetaan Bidang Tanah setelah pelaksanaan Pengukuran diharapkan sesuai dengan Petunjuk Teknis Pengukuran Dan Pemetaan Bidang Tanah Sistematik Lengkap Nomor: 01/JUKNIS-300/2016, Tanggal: 30 Desember 2016.

Permasalahan pemetaan dapat digolongkan menjadi beberapa bagian berikut beserta solusi yang seharusnya dilaksanakan oleh petugas pemetaan sesuai dengan peraturan yang berlaku, antara lain:

\section{a. Pembuatan Peta Bidang}

Pembuatan Peta Bidang tanah sudah memiliki aturan yang dikeluarkan oleh Kementerian Agraria Dan Tata Ruang/Badan Pertanahan Nasional melalui Petunjuk Teknis. Tetapi hal tersebut masih belum secara terperinci sehingga masih terdapat beberapa pemahaman oleh pelaksana pada Kantor Pertanahan.

Ketidakseragaman tersebut seharusnya diatasi dengan mengacu pada peraturan Instansi atau Kementerian lain yang berkompeten dengan pemetaan atau pembuatan peta contohnya Peraturan Kepala Badan Informasi Geospasial Nomor 15 Tahun 2014 tentang Pedoman Teknis Ketelitian Peta Dasar menyebutkan "Peraturan Kepala Badan Informasi Geospasial ini merupakan peraturan kepala yang mengatur pedoman teknis mengenai syarat dan ketentuan dalam standar ketelitian peta dasar".

b. Bidang Tanah tidak sesuai dengan Tata Ruang

Bidang Tanah yang telah terukur sesuai dengan penunjukan batas bidang tanah oleh pemohon setelah dilakukan pemetaan ternyata masuk dalam kawasan yang tidak diperbolehkan diberikan ijin hak atas tanah. 
Padahal keadaan fisik bidang tanah yang diukur telah dikuasai secara utuh dan dalam waktu yang cukup lama sehingga tidak sesuai lagi dengan penataan ruang yang telah disahkan oleh Pemerintah Daerah setempat. Upaya pelaksanaan perencanaan penataan ruang yang bijaksana adalah kunci dalam pelaksanaan tata ruang agar tidak merusak lingkungan hidup, dalam konteks penguasaan Negara atas dasar sumber daya alam, menurut hemat penulis melekat di dalam kewajiban Negara untuk melindungi, melestarikan dan memulihkan lingkungan hidup secara utuh. $^{13}$

Pembuatan peraturan daerah mengenai Rencana Tata Ruang Wilayah Kabupaten seharusnya mempertimbangkan kondisi fisik terkini atas wilayah tersebut dan tetap pada prinsip demi mensejahterakan rakyat melalui pembagian tanah. Rencana umum peruntukan tanah harus sepenuhnya didasarkan kepada kondisi obyektif fisik tanah dan keadaan lingkungan, oleh karena itu rencana umum peruntukan tanah di tingkat pusat, provinsi, dan kabupaten/kota seharusnya memiliki kesamaan. Rencana umum persediaan tanah adalah suatu usaha pemenuhan kebutuhan tanah untuk berbagi pembangunan, yang dikaitkan dengan rencana umum peruntukan tanah. Rencana umum penggunaan tanah adalah usaha pemenuhan tanah untuk rencana pembangunan atau program-program yang sudah ada. ${ }^{14}$

Pelaksanaan rencana umum yang dimaksud dalam Pasal 14 ayat (1) UUPA dilaksanakan pula oleh Pemerintah Daerah untuk mengatur persediaan dan peruntukan dan penggunaan bumi, air serta ruang

13 Juniarso Ridwan dan Achmad Sodik, 2016, Hukum Tata Ruang dalam konsep kebijakan otonomi daerah, Nuansa, Bandung, hlm. 29.

14 Juniarso Ridwan dan Achmad Sodik, Ibid.,hlm. 42. angkasa untuk daerahnya sesuai dengan keadaan daerahnya masing-masing. ${ }^{15}$

Menurut Mieke Komar Kantaatmadja, selain pada aspek-aspek tujuan penataan ruang, penatagunaan tanah pun harus mengacu pada kebijaksanaan dasar mengenai pertanahan yang terkandung dalam UUPA dan undangundang lain yang berkaitan dengan penggunaan tanah. ${ }^{16}$

Koesnadi Hardjasoemantri mengemukakan asas pelestarian kemampuan lingkungan yang serasi dan seimbang, dikaitkan dengan melestarikan (melanggengkan, tidak mengubah) kemampuan lingkungan, sehingga dalam setiap proses pembangunan selalu diupayakan untuk meniadakan atau mengurangi dampak negatife, agar keadaan lingkungan menjadi serasi, seimbang pada tingkatan yang baru. ${ }^{17}$

\section{PENUTUP KESIMPULAN DAN SARAN}

Adapun kesimpulan dalam penelitian ini yaitu Permasalahan pengukuran dan pemetaan untuk pendaftaran tanah terjadi karena kegiatan sosialisasi yang kurang mengena pada masyarakat sebagai pemilik bidang tanah, pemasangan dan penunjukan Batas Bidang Tanah, alas hak atas tanah, kurangnya peralatan dan tenaga pengukuran. Sedangkan pada pemetaan permasalahannya terkait pembuatan peta bidang, dan bidang tanah yang tidak sesuai dengan tata ruang.

Mengatasi masalah pengukuran dan pemetaan bidang tanah untuk pendaftaran

15 Arba, 2017, Hukum Tata Ruang Dan Tata Guna Tanah Prinsip-Prinsip Hukum Perencanaan Penataan Ruang dan Penataagunaan Tanah, Jakarta Timur, hlm. 37.

${ }^{16}$ Supriadi, Loc.cit., hlm. 261.

17 Koesnadi Hardjasoemantri, 2000, Hukum Tata Lingkungan, Gadjah Mada University Press, Yogyakarta, hlm. 89. 
tanah dengan mengikuti petunjuk teknis Petunjuk Teknis Nomor: 01/JUKNIS400/XII/2016 tentang Percepatan Pelaksanaan Pendaftaran Tanah Sistematis Lengkap Bidang Yuridis dan Petunjuk Teknis Nomor: 01/JUKNIS-300/2016 tentang Pengukuran dan Pemetaan Bidang Tanah Sistematis Lengkap yang menjelaskan tahap-tahap dalam pelaksanaan pengukuran dan pemetaan bidang tanah dengan teliti dan dipatuhi semua ketentuan yang telah dibuat.

Adapun saran yang diberikan dalam penelitian ini bahwa permasalahan pengukuran dan pemetaan untuk pendaftaran tanah yang terjadi sebaiknya dijadikan suatu masukan untuk menerbitkan peraturan baru dalam rangka memperbaiki pelayanan terhadap masyarakat agar lebih memahami program-program terbaru dari Kementerian Agraria dan Tata Ruang/Badan Pertanahan Nasional, dan juga meningkatkan Sumber Daya Manusia di lingkungan Kementerian Agraria dan Tata Ruang/Badan Pertanahan Nasional dengan memberikan pelatihan terhadap para petugas ukur untuk menentukan sikap ketika menghadapi permasalahan di lapangan, serta memperbaiki peta lama yang sudah terbit sertipikat maupun yang masih dalam bentuk Gambar Situasi sehingga menghindari tumpang tindih, ditambah membuat server khusus bagi tiaptiap Provinsi maupun Kabupaten/Kota disesuaikan dengan anggaran yang dimiliki.

Mengatasi masalah pengukuran dan pemetaan bidang tanah untuk pendaftaran tanah adalah dengan melaksanakan perencanaaan kegiatan dengan matang dengan mengikuti Petunjuk Teknis yang telah dirancang dan dibuat oleh Kementerian Agraria dan Tata Ruang/Badan Pertanahan Nasional Republik Indonesia untuk menghindari permasalahan baru yang akan muncul apabila tidak sesuai dengan Petunjuk Teknis pelaksanaan kegiatan.

\section{DAFTAR PUSTAKA}

\section{Buku/Literatur:}

Arba, 2017, Hukum Tata Ruang Dan Tata Guna Tanah Prinsip-Prinsip Hukum Perencanaan Penataan Ruang dan Penataagunaan Tanah, Jakarta Timur;

Farida Fitriyah, 2016, Hukum Pengadaan Tanah Transmigrasi, Setara Press, Malang, Jatim;

Jarot Widya Muliawan, 2015, Pemberian Hak Milik Untuk Rumah Tinggal Sebuah Kajian Normatif Untuk Keadilan Bagi Masyarakat, Buku Litera Yogyakarta, Yogyakarta;

Juniarso Ridwan dan Achmad Sodik, 2016, Hukum Tata Ruang dalam konsep kebijakan otonomi daerah, Nuansa, Bandung;

Koesnadi Hardjasoemantri, 2000, Hukum

Tata Lingkungan, Gadjah Mada University Press, Yogyakarta;

Supriadi, 2016, Hukum Agraria, Sinar Grafika, Jakarta;

Umar Said Sugiharto, (et.al.), 2015, Hukum Pengadaan Tanah Pengadaan Hak Atas Tanah untuk Kepentingan Umum Pra dan Pasca Reformasi, Setara Press, Malang, Jatim;

Urip Santoso, 2005, Hukum Agraria dan Hak-hak Atas Tanah, Kencana dan Prenada Media, Jakarta;

Waskito \& Hadi Arnowo, 2015, Cara 
Praktis Memahami Bidang Agraria (Pertanahan), PT. Media Adji Internasional, Jakarta Timur;

Wira Franciska, 2016, Kepastian Hukum Pemegang HGB Di Atas HPL Dalam Perjanjian Penjaminan Kredit Perbankan, Alfabeta, CV, Bandung;

\section{Peraturan-Perundangan:}

Undang-Undang Republik Indonesia Nomor 5 Tahun 1960 Tentang Peraturan Dasar Pokok-Pokok Agraria;

Peraturan Pemerintah Republik Indonesia Nomor 24 Tahun 1997 Tentang Pendafratan Tanah;

Peraturan Menteri Negara Agraria/Kepala Badan Pertanahan Nasional Nomor 3 Tahun 1997 Tentang Ketentuan Pelaksanaan Peraturan Pemerintah Nomor 24 Tahun 1997 Tentang Pendaftaran Tanah;

Peraturan Menteri Agraria Dan Tata

Ruang/Kepala Badan Pertanahan Nasional Republik Indonesia Nomor 35 Tahun 2016 Tentang Percepatan Pelaksanaan Pendaftaran Tanah Sistematis Lengkap;

Peraturan Menteri Agraria Dan Tata Ruang/Kepala Badan Pertanahan Nasional Republik Indonesia Nomor 1 Tahun 2017 Tentang Perubahan Atas Peraturan Menteri Agraria Dan Tata Ruang/Kepala Badan Pertanahan Nasional Nomor 35 Tahun 2016 Tentang Percepatan Pelaksanaan Pendaftaran Tanah Sistematis Lengkap;

Peraturan Menteri Agraria dan Tata Ruang/Kepala Badan Pertanahan
Nasional Republik Indonesia Nomor 33 Tahun 2016 Tentang Surveyor Kadaster Berlisensi;

Peraturan Menteri Agraria dan Tata

Ruang/Kepala Badan Pertanahan Nasional Republik Indonesia Nomor 28 Tahun 2016 Tentang Percepatan Program Nasional Agraria Melalui Pendaftaran Tanah Sistematis;

Peraturan Kepala Badan Informasi

Geospasial Nomor 15 Tahun 2014 tentang Pedoman Teknis Ketelitian Peta Dasar.

\section{Sumber Lain:}

Buku Pegangan Juru Ukur;

Petunjuk Pelaksanaan Pendaftaran Tanah Masyarakat Menteri Agraria dan Tata Ruang/Kepala Badan Pertanahan Nasional Nomor: 1756/15.1/IV/2016, tanggal 14 April 2016;

Petunjuk Teknis Nomor: 01/JUKNIS400/XII/2016 Tentang Percepatan Pelaksanaan Pendafataran Tanah Sistematis Lengkap Bidang Yuridis;

Petunjuk Teknis Pengukuran Dan Pemetaan Bidang Tanah Sistematik Lengkap Nomor: $\quad 01 / J U K N I S-300 / 2016$, Tanggal: 30 Desember 2016;

Kamus Besar Bahasa Indonesia (KBBI) http://kbbi.web.id/ukur, diakses tanggal 16 Mei 2017, 17.47 WIB;

http://kbbi.web.id/peta, diakses tanggal 24 Mei 2017, 10.20 WITA;

http://kbbi.web.id/daftar, diakses tanggal 24 Mei 2017, 12.43 WITA;

http://kbbi.web.id/tanah, diakses tanggal 24 Mei 2017, 13.32 WITA;

http://kbbi.web.id/sistematis, diakses tanggal 9 Juni 2017, 14.10 WITA; 
http://kbbi.web.id/lengkap, diakses tanggal

9 Juni 2017, 14.33 WITA;

http://kbbi.web.id/sosialisasi, diakses

tanggal 8 September 2017, 20.00

WITA;

http://kbbi.web.id/penyuluhan, diakses tanggal 8 September 2017, 20.20 WITA;

Pendaftaran Tanah Sistematis Lengkap (PTSL)

http://kecamatanbandungkulon.org/pendafta ran-tanah-sistematis-lengkap-ptsl/, diakses tanggal 24 Mei 2017, 15.13 WITA; 